\title{
Legal Consequences of Underage Marriage (Case Study of Elopement of Bajau Tribe in Lagasa Village, Muna Regency)
}

\author{
La Ode Munawir, Suriani B. Tolo, Yaya Alfia \\ Faculty of Law, Southeast Sulawesi University
}

\begin{abstract}
Marriage Law in Indonesia is regulated through Law Number 16 of 2019 concerning Amendments to Law Number 1 of 1974 concerning Marriage. Through this Law, the provisions of the general public, Article 7 (1) Marriage is only permitted if the man and woman have reached the age of 19 (nineteen) years. (2) In the event that there is a deviation from the age provisions as referred to in paragraph (1), the parents of the male and/or female parents may request a dispensation from the Court on the grounds that it is very urgent, accompanied by sufficient supporting evidence. However, in reality in the community, especially in the village of Lagasa, Muna Regency, there are other phenomena that are contrary to the law on underage marriage, this research uses the empirical legal research method. have not met the applicable legal requirements, other legal consequences of course from unregistered marriages have implications for the civil rights of wives and children later in life.
\end{abstract}

Keywords: Marriage, Minors, Lagasa Village

DOI: $10.7176 / \mathrm{JLPG} / 117-01$

Publication date: January $31^{\text {st }} 2022$

\section{Introduction}

Philosophically, according to the law on child protection, children are buds, potentials, and the younger generation who succeeds in the ideals of the nation's struggle, has a strategic role, characteristics, and special characteristics so that it must be protected from all forms of inhumane treatment that result in violations of human rights. So that the marriage below must be prevented and not allowed to continue to occur in the community.

However, in reality underage marriage in ancient times until today is still a lot going on. However, in the case that underage marriages are forced to be carried out, the marriage law still provides the possibility of deviations. $^{1}$

This is regulated in Article 7 paragraph (1) Marriage is only permitted if the man and woman have reached the age of 19 (nineteen) years. (2) In the event that there is a deviation from the age provisions as referred to in paragraph (1), the parents of the male and/or female parents may request a dispensation from the Court on the grounds that it is very urgent, accompanied by sufficient supporting evidence. ${ }^{2}$ And this is given to avoid unwanted things in children such as adultery and others. ${ }^{3}$

From this age limit, it can be interpreted that Law Number 1 of 1974 does not require the implementation of underage marriages which have been determined by Law Number 1 of 1974. Underage marriage is not something new in Indonesia. This practice has been around for a long time with so many perpetrators. Not in the big city, not in the interior. The reasons also vary, due to economic problems, low education, cultural understanding and certain religious values, and so on. ${ }^{4}$

Lagasa Village, Duruka Subdistrict, Muna Regency, Southeast Sulawesi, the majority of which are Bajau people with the majority of their livelihoods being fishermen who almost every month have a pair of children who elope (silayyang) where they always do silayyang (elopement) during the middle of the full moon or in the middle of the full moon. when the fishermen take a break from doing work as sailors. ${ }^{5}$

the phenomenon of elopement very often occurs in the Bajau tribe of Lagasa Village which is usually caused by several educational factors where almost most of those who elope are children who have dropped out of school or who have never attended school whose daily activities are only playing and participating in earning a living as a source of income. fisherman;

Economic factors where the parents of the man do not have enough money to propose to the girl who is the boyfriend of the boy, the factor of the parents or family of the woman does not approve of her daughter's relationship with the man who is her child's lover so that both partners they do silayyang so that they are not

\footnotetext{
${ }^{1}$ Zulfiani, Kajian Hukum Terhadap Perkawinan Anak Di Bawah Umur Menurut Undang-Undang Nomor 1 Tahun 1974, Jurnal Hukum Samudra Keadilan Volume 12, Nomor 2, Juli-Desember 2017, Hlm 212

${ }^{2}$ Lihat Undang-Undang Republik Indonesia Nomor 16 Tahun 2019 Tentang Perubahan Atas Undang-Undang Nomor 1 Tahun 1974 Tentang Perkawinan

${ }^{3}$ Zulfiani, Op, Cit., hlm 212.

${ }^{4}$ Ibid

${ }^{5}$ Yaya Alfia, dkk, Perspektif Hukum Adat Kawin Lari (Silayyang) Suku Bajau Di Desa La Gasa Kabupaten Muna, Jurnal Hukum UNISSULA Volume 37 No. 1, Mei P-ISSN: 1412-2723, Hlm 26
} 
separated. ${ }^{1}$

Elopement (silayyang) from year to year continues to show an increase. From 2019 to 2020, there were almost 18 young couples who performed the Silayyang practice, generally those who eloped were children who dropped out or did not go to school and even minors. Usually those who do this are actually just regular dating, but because the relationship is opposed by their parents, they elope so they don't get separated. ${ }^{2}$

Based on the description of the background of the problem above, there are legal issues that need to be studied in research on legal behavior that is contrary to the provisions of marriage law in Indonesia. Marriage under public must be prevented in order to protect children from various negative impacts that will arise. For this reason, there is a need for legal research to protect children as buds, potentials and the nation's next generation.

Formulation of the problem

1. How is the marriage of minors viewed from the customary law system of the Bajau tribal community, Lagasa Village, Muna Regency?

2. How are the legal consequences of underage marriage reviewed in the case of elopement in Lagasa Village, Muna Regency?

\section{Research methods}

This study uses an empirical juridical research method that examines primary data regarding the legal consequences of child marriage under age. Case Study of Lari-Lari in Lagasa Village, Muna Regency. The research uses a juridical approach (law is seen as a norm or das sollen) and an empirical approach (law as a social, cultural or das sein reality) to analyze the problem of underage marriages that are not recorded and are contrary to Law no. 1/1974. Data collection techniques are carried out through direct observation or observation using field studies or case studies on the phenomenon of underage marriage. Then the author conducted structured and unstructured interviews, the data that had been collected was then analyzed using legal materials to examine and discuss and find answers to problems that had been found in the field. So that it can find answers as legal facts in this study.

\section{Discussion}

\subsection{The marriage of minors is seen from the customary law system of the Bajau tribal community, Lagasa village, Muna Regency}

\subsubsection{Marriage according to Law no. 1 of 1974}

The law applies to marriage in Indonesia subject to the provisions of law no. 1 of 1974 as referred to in the provisions of Article 1 "Marriage is an inner and outer bond between a man and a woman as husband and wife with the aim of forming a happy and eternal family (household) based on God Almighty.

In addition, the marriage law is legal, if it is carried out according to the law of each religion and belief (stipulations of article 2 paragraph 1), to make administrative guidelines, marriages are required to be recorded as stipulated in article 2 paragraph (2) that each Each marriage is recorded according to the applicable laws and regulations.

The principles or principles contained in the marriage law in Indonesia are as follows:

a. The purpose of marriage is to form a happy and eternal family. For that husband and wife need to help and complement each other, each can develop his personality to help and achieve spiritual and material well-being.

b. In this law it is stated that a marriage is valid if it is carried out according to the law of each religion and belief; and besides that every marriage must be recorded according to the applicable laws and regulations. The recording of each marriage is the same as the recording of important events in a person's life, for example births, deaths which are stated in certificates, an official certificate which is also included in the register of records.

c. This law adheres to the principle of monogamy. Only if it is desired by the person concerned, because the law and religion of the person concerned allows it, a husband can have more than one wife. However, the marriage of a husband with more than one wife, even though it is desired by the parties concerned, can only be carried out if certain conditions are met and decided by the Court.

d. This law adheres to the principle that the prospective husband and wife must have matured in mind and body to be able to carry out a marriage, so that they can realize the purpose of marriage properly without ending in divorce and obtaining good and healthy offspring. For this reason, marriages between prospective husbands and wives who are still under age must be prevented. In addition, marriage has a relationship with population problems. It turns out that a lower age limit for a woman to marry results in a higher birth rate when compared to a higher age limit. 
Underage marriage is a marriage carried out by a man and a woman where each party has not reached the age of 21 years and is still under the authority of parents so that all actions cannot be legally accounted for. ${ }^{1}$

\subsubsection{Age Limits for Men and Women in Marriage}

The granting of a marriage permit for a man and a woman prior to any changes, (1) Marriage is only permitted if the man has reached the age of 19 (nineteen) years and the woman has reached the age of 16 (sixteen) years. After that, a change was made with the consideration "The Constitutional Court of the Republic of Indonesia has issued a Constitutional Court Decision No. 22/PUU-XV/2017 which one of the considerations of the Constitutional Court in the decision is "However, when the difference in treatment between men and women has an impact on or hinders the fulfillment of rights -basic rights or constitutional rights of citizens, whether included in the group of civil and political rights as well as economic, educational, social and cultural rights, which should not be distinguished solely on the basis of gender, then the distinction thus clearly constitutes discrimination." In the same consideration, it is also stated that the regulation of the minimum age limit for marriage that differs between men and women not only creates discrimination in the context of the implementation of the right to form a family as guaranteed in Article 28B paragraph (1) of the 1945 Constitution, but also creates discrimination against the protection and fulfillment of rights. children as guaranteed in Article 28B paragraph (2) of the 1945 Constitution. In this case, when the minimum age of marriage for women is lower than for men, legally women can form a family faster.

Based on this consideration then Law no. 1 of 1974 there was an amendment to Law No. 16 of 2019 then in the provisions of article 7 paragraph marriage is only permitted if the man and woman have reached the age of 19 (nineteen) years. However, in implementation in the Bajau tribal community, this rule has not been implemented effectively due to the cultural beliefs of the Bajau tribal community that does not provide an age limit for drinks for men and women.

\subsubsection{Study of the customary law of the Bajau tribe, marriage of children under age}

The meaning of marriage for customary law is important because "in customary law it is believed that marriage is not only an important event for their deceased ancestors. The ancestral spirits of both parties are also expected to bless the continuity of their household, which will be more harmonious and happy. Once the importance of this marriage, then the marriage was always and continuously accompanied by various ceremonies complete with offerings. Forms of marriage of minors in the village of Lagasa include marriages in the sala of marriages carried out by men and women in the homes of traditional parents after being married by traditional parents, then 1 or two weeks later the man and woman re-conduct the marriage agreement in front of the leader.

In addition, the Silayyang incident that occurred in Lagasa Village, Muna Regency, was a marriage that was considered valid based on consensual consent. In the village of Lagasa silay which is a common thing because it has become a habit when the male and female partners are not approved by the woman's parents, not only that, elopement is also carried out by those who are still classified as minors so that it is contrary to the marriage law. ${ }^{2}$

There is also no customary law that regulates the age limit for marriage, therefore, if there is an underage silayyang then they can still be married according to the pillars of marriage and can live as husband and wife but underage marriages do not get legal legality because they are not recorded by the marriage registrar. The study of the effectiveness of the law cannot be separated from aspects of community behavior in law. ${ }^{3}$

\subsection{The legal consequences of underage marriage are reviewed in the case of elopement in Lagasa village, Muna Regency}

\subsubsection{Legal Impact of the Marriage Law}

The legal impact arising from a marriage that does not meet the age requirements is reviewed from the marriage law "Marriage is only permitted if a man and a woman have reached the age of 19 (nineteen) years." Underage marriage is not in accordance with the spirit of the marriage law, the reason why the age limit for a child's marriage must be limited, the age limit in question is considered to have matured physically and mentally to be able to carry out a marriage in order to realize the purpose of marriage properly without ending in divorce and getting offspring who healthy and quality. It is also hoped that an increase in the age limit higher than 19 (sixteen) years for women to marry will result in a lower birth rate and reduce the risk of maternal and child mortality. In addition, it can also fulfill the rights of children so as to optimize the growth and development of children including parental assistance and provide children with access to education as high as possible.

\subsubsection{Legal Impact of the Child Protection Act}

Child is someone who is not yet 18 (eighteen) years old, including children who are still in the womb. Law Number 35 of 2014 concerning Child Protection Article 26 (1) Parents are obligated and responsible for:

\footnotetext{
${ }^{1}$ Hasan Bastomi, Pernikahan Dini Dan Dampaknya (Tinjauan Batas Umur Perkawinan Menurut Hukum Islam Dan Hukum Perkawinan Indonesia), YUDISIA, Vol. 7, No. 2, Desember 2016, hlm 371

${ }^{2}$ Yaya Alfia, Op., Cit., hlm 28

${ }^{3}$ Ibid
} 
nurturing, nurturing, educating and protecting children, nurturing children according to their abilities, talents and interests and; prevent child marriage.

\subsubsection{Marriage is not registered at KUA}

Law No. 1 of 1974 Article 2 Paragraph (2) mandates that the implementation of marriages be recorded. In practice, for people who adhere to the Islamic religion, marriage registration is carried out by officers from the sub-district Religious Affairs Office. The purpose of recording a marriage is to make the marriage bond legally valid and the consequences of marriage such as the birth of a child have legal force and can be registered in accordance with applicable laws and regulations. ${ }^{1}$

For those who have not reached adulthood according to the marriage law for men and women of 19 years, the local religious affairs office will not register the marriage between a man and a woman if they do not meet the age requirements and obtain dispensation from the local court in accordance with the provisions of Article 7 paragraph (1) Marriage is only permitted if the man and woman have reached the age of 19 (nineteen) years. (2) In the event that there is a deviation from the age provisions as referred to in paragraph (1), the parents of the male and/or female parents may request a dispensation from the Court on the grounds that it is very urgent, accompanied by sufficient supporting evidence. ${ }^{2}$ The law provides an opportunity to carry out marriages but by asking the court for dispensation with urgent reasons accompanied by sufficient evidence.

\subsubsection{Loss of Wife's Civil Rights}

Underage marriages carried out by men and women who do not meet the marriage requirements as described above, the marriage will not be registered if it does not get dispensation from the court accompanied by sufficient evidence, the local religious affairs office will not record the marriage. In addition, as a result of not being recorded in the Office of Religious Affairs, administratively the marriage is not recognized by the state, although in Islamic law it is still recognized because it has fulfilled the elements of the pillars and requirements of marriage. So that marriages that are not registered, the civil rights of a wife to a marriage are not recognized by the state because the reason for the marriage is that the marriage is carried out in the hands of which does not get recognition from the state so that this is very detrimental to the civil rights of a wife.

\subsubsection{Loss of Children's Civil Rights}

In addition to the loss of a wife's civil rights in marriage law in Indonesia, the rights of a child born without marriage registration by the mother and father are not granted civil rights to the child. In accordance with the provisions of Article 43 (1) of Law Number 1 of 1974, children born outside of marriage only have a civil relationship with their mother and their mother's family.

However, based on the Constitutional Court's Decision Number 46/PUU-VIII/2010, it is stated that Article 43 paragraph (1) of Law No. 1 of 1974 concerning Marriage which reads "Children born outside of marriage only have a civil relationship with their mother and their mother's family". with the 1945 Constitution and does not have binding legal force as long as it is interpreted to eliminate civil relations with men which can be proven based on science and technology and/or other evidence according to the law that turns out to have blood relations as the father, so the paragraph must read, "The child who born out of wedlock has a civil relationship with his mother and his mother's family as well as with a man as his father which can be proven based on science and technology and/or other evidence according to the law having blood relations, including civil relations with his father's family.

Based on the decision, the civil rights can be granted through evidence based on science and technology.

\section{Conclusion}

Marriage of minors is seen from the customary law system of the Bajau tribal community, Lagasa Village, Muna Regency. Underage marriages in the Bajau tribal community in customary law communities do not regulate the age limit for marriage, therefore if there is an underage silay then they can still be married according to the pillars of marriage and can live as husband and wife but underage marriages do not get legal legality because not registered by the marriage registrar. The study of the effectiveness of the law cannot be separated from aspects of community behavior in law.

Legal Consequences of Underage Marriage Reviewed in the Elopement Case in Lagasa Village, Muna Regency, underage marriages cannot be registered with the marriage registrar because they are contrary to the provisions of law number 16 of 2019 concerning amendments to law number 1 of 1974 concerning marriage , the loss of civil rights of a wife to her husband because she did not get recognition from the state on her marital status because it was not recorded at the local Religious Affairs Office, the civil rights of a child to his biological father must be proven based on science and technology and/or other evidence according to the law having blood relationship, including civil relationship with the father's family, if it cannot be proven then the child has no civil relationship with his father

${ }^{1}$ Kustini, Perkawinan tidak Tercatat: Pudarnya Hak-Hak Perempuan (Studi di Kabupaten Cianjur), HARMONI Mei - Agustus 2013, hlm. 73

${ }^{2}$ Lihat Undang-Undang Republik Indonesia Nomor 16 Tahun 2019 Tentang Perubahan Atas Undang-Undang Nomor 1 Tahun 1974 Tentang Perkawinan 


\section{References}

Hasan Bastomi, Early Marriage and Its Impact (Review of Marriage Age Limits According to Islamic Law and Indonesian Marriage Law), YUDISIA, Vol. 7, No. 2, December 2016

Kustini, Unregistered Marriages: The Fading of Women's Rights (Study in Cianjur Regency), HARMONY May August 2013

Law of the Republic of Indonesia Number 16 of 2019 concerning Amendments to Law Number 1 of 1974 concerning Marriage

Sherlin Darondos, Child Marriage and Its Legal Consequences, Lex et Societatis, Vol. II/No. 4/May/2014

Yaya Alfia, et al, Perspective of the Customary Law of Marriage (Silayyang) of the Bajau Tribe in La Gasa Village, Muna Regency, UNISSULA Legal Journal Volume 37 No. 1, May P-ISSN: 1412-2723

Zulfiani, Legal Studies on Marriage of Minors According to Law Number 1 of 1974, Journal of Samudra Justice Law Volume 12, Number 2, July-December 2017 